\title{
The occurrence of Plasmodiophora brassicae in agricultural soils in Wielkopolska region, in 2011-2012
}

\author{
Występowanie Plasmodiophora brassicae w glebach \\ z uprawami roślin rolniczych w Wielkopolsce, w latach 2011-2012
}

\author{
Małgorzata Jędryczka ${ }^{1}$, Marek Korbas ${ }^{2}$, Ewa Jajor ${ }^{2}$, Jakub Danielewicz ${ }^{2}$, Joanna Kaczmarek ${ }^{1}$
}

\begin{abstract}
Summary
The protozoan pathogen Plasmodiophora brassicae - responsible for clubroot, is a considerable threat to cruciferous vegetables and oilseed rape in Poland. So far, the occurrence of $P$. brassicae has been shown in plants and soil obtained from fields, where clubroot was found on crop or weed plants belonging to Brassicaceae family. The aim of this study was to evaluate the occurrence of the pathogen in randomly collected samples of agricultural soils in Wielkopolska province (central-west Poland) in 2011-2012. Soil samples were obtained from 196 fields, encompassing 31 rural and 4 urban counties of Wielkopolskie voivodeship (province). The presence of the pathogen was examined by bioassay on plants of a susceptible genotype of Brassica rapa ssp. pekinensis and a susceptible variety of oilseed rape. In most cases, the soil sample was free from pathogen quantities sufficient to cause symptoms of clubroot on susceptible cruciferous plants. The pathogen was not detected in any soil of municipal counties of Wielkopolska, but they were found in eight rural counties (25.8\%). A map of Wielkopolska with the present occurrence of the pathogen in randomly selected samples of agricultural soils in 2011-2012 has been drawn. Based on our monitoring it can be concluded that $P$. brassicae is currently present, but not widely spread in agricultural soils of Wielkopolska. The actions of a preventive character can significantly reduce the further spread of this damaging pathogen.
\end{abstract}

Key words: winter oilseed rape, clubroot, Plasmodiophora brassicae, agricultural soil, preventive action

\begin{abstract}
Streszczenie
Pierwotniak Plasmodiophora brassicae wywołujący kiłę kapusty stanowi zagrożenie w uprawach kapustowatych roślin warzywnych i rzepaku w Polsce. Dotychczas występowanie P. brassicae wykazano w próbach porażonych roślin i w glebie z pól, na których stwierdzono objawy kiły kapusty na roślinach uprawnych lub chwastach z rodziny kapustowatych. Celem pracy było określenie nasilenia występowania patogena w losowo pobranych próbach gleb rolniczych w Wielkopolsce. Próby gleby pobrano ze 196 pól z terenu wszystkich powiatów wiejskich (31) i miejskich (4) województwa wielkopolskiego. Występowanie pierwotniaka badano przy pomocy biotestu na roślinach podatnego genotypu Brassica rapa ssp. pekinensis oraz na roślinach rzepaku ozimego, podatnej na tego patogena odmiany Monolit. W większości prób gleby nie wykryto sprawcy w ilości wystarczającej do wywołania objawów choroby u podatnych roślin kapustowatych. Patogena nie wykryto w żadnej glebie spośród gmin miejskich, natomiast jego obecność stwierdzono na polach ośmiu powiatów wiejskich (25,8\%). Dla Wielkopolski wykreślono aktualną mapę z zaznaczonymi powiatami, w których stwierdzono $P$. brassicae w losowo pobieranych próbach gleby $z$ uprawami rolniczymi. Stwierdzono, iż pierwotniak $P$. brassicae występuje, choć nieczęsto spotykany jest w glebach rolniczych w Wielkopolsce. Działania o charakterze prewencyjnym mogą w znacznym stopniu ograniczyć dalsze rozpowszechnianie się tego groźnego patogena.
\end{abstract}

Słowa kluczowe: rzepak ozimy, kiła kapusty, Plasmodiophora brassicae, gleba rolnicza, działanie prewencyjne

\footnotetext{
Instytut Genetyki Roślin Polskiej Akademii Nauk Strzeszyńska 34, 60-479 Poznań jkac@igr.poznan.pl

${ }^{2}$ Instytut Ochrony Roślin - Państwowy Instytut Badawczy

Władysława Węgorka 20, 60-318 Poznań
} 


\section{Wstęp / Introduction}

Kiła kapusty wywoływana przez pierwotniak Plasmodiophora brassicae Woronin już od wielu lat jest groźna i powszechnie występująca chorobą roślin kapustowatych w Europie i Ameryce Północnej (Robak 1991; Agrios 2005; Lüders i wsp. 2011), a od kilku lat stanowi poważne wyzwanie dla plantatorów rzepaku w Polsce (Korbas i wsp. 2009; Korbas i Jajor 2013). Choroba spotykana jest na znacznym obszarze uprawy rzepaku, choć nasilenie jej występowania w poszczególnych regionach kraju jest bardzo zróżnicowane. Zgodnie z ostatnimi doniesieniami Koniecznego (2012) w Polsce patogen opanował 250 tys. ha gleb objętych uprawą rzepaku. Istnieje możliwość dalszego rozszerzania zasięgu występowania tej choroby. Informacje te są bardzo niepokojące ze względu na wyjątkową żywotność zarodników przetrwalnikowych, które po zakażeniu gleby mogą w niej przetrwać do 20 lat, zachowując swoją infekcyjność (Dixon 2009).

Szybkość rozprzestrzeniania się choroby jest wyjątkowo wysoka. Stwierdzono, że po trzech latach od wystąpienia objawów na niewielkiej liczbie roślin, w sprzyjających warunkach do rozwoju sprawcy, choroba może opanować całą plantację. Taka sytuacja dotyczy uprawy rzepaku bez zastosowania płodozmianu, co jest niestety zjawiskiem spotykanym w wielu regionach intensywnej uprawy rzepaku. Badania prowadzone w Kanadzie, gdzie patogena zaobserwowano na rzepaku stosunkowo niedawno (Pageau i wsp. 2006; Strelkov i wsp. 2009) wykazały, iż występowanie $P$. brassicae na polach $\mathrm{z}$ tą uprawą prawie zawsze związane było ze znacznym skróceniem płodozmianu (Gossen i wsp. 2013). Podobna sytuacja występuje na północy i północnym wschodzie Niemiec oraz w niektórych rejonach Francji, Anglii, Skandynawii i w innych częściach Europy, gdzie zaobserwowano silnie zainfekowane pola, a tendencja ta nasila się (Rimmer i wsp. 2007; Lüders i wsp. 2011). Ze względu na częstą praktykę wprowadzania rzepaku do płodozmianu co 2 lata, a nawet corocznie, istnieje duża obawa, że w Polsce nastąpi dalsze zanieczyszczenie terenów rolniczych tym groźnym i trwałym mikroorganizmem chorobotwórczym. Jest to możliwe tym bardziej, że patogen łatwo i szybko rozprzestrzenia się przede wszystkim $\mathrm{z}$ wodą oraz $\mathrm{z}$ cząsteczkami gleby zanieczyszczającymi maszyny rolnicze i koła środków transportu. Jak dotąd, badania w Polsce prowadzono wyłącznie na polach, na których wcześniej zaobserwowano objawy kiły kapusty na roślinach rzepaku. Nie jest zaskoczeniem zatem fakt, iż w próbach gleby pobranych $\mathrm{z}$ zanieczyszczonych pól stwierdzono występowanie tego patogena. Dotychczas nie prowadzono jednak monitoringu losowo wybranych gleb z upraw rolniczych pod względem obecności zarodników przetrwalnikowych.

Celem badań było określenie nasilenia występowania $P$. brassicae w glebach użytkowanych rolniczo, pobranych $\mathrm{z}$ pól $\mathrm{z}$ uprawą roślin innych aniżeli rzepak lub pól rzepaku, na których nie stwierdzono kiły kapusty. Badania dotyczyły obszaru Wielkopolski. W celu uzyskania obrazu nasilenia występowania patogena w całym województwie próby gleby pobrano z terenu wszystkich powiatów wiejskich i miejskich.

\section{Materiały i metody / Materials and methods}

Próby pobrano z gleb wykorzystywanych rolniczo na terenie 31 powiatów wiejskich i 4 powiatów miejskich województwa wielkopolskiego. Z każdego powiatu wiejskiego pobrano co najmniej 5 prób, a $\mathrm{z}$ miejskiego po 2-3 próby. Glebę pobierano próbnikiem $\mathrm{z}$ warstw rozpoczynających się na powierzchni gleby do głębokości $20 \mathrm{~cm}$. Do tego celu wykorzystywano próbnik Spychalskiego i Kosiady (Wzór użytkowy 117084) o pojemniku w kształcie odwróconego stożka ściętego. Próbnik ten umieszczano na wkrętarce działającej na baterie akumulatorowe. W przypadku szczególnie twardego podłoża uniemożliwiającego zastosowanie świdra, glebę pobierano szpadlem, saperką i łopatkami ogrodniczymi, dbając o zebranie warstw ziemi z głębokości 0-20 cm. Każdorazowo pobierano próbę około $2 \mathrm{~kg}$ gleby, po $200 \mathrm{~g}$ gleby z 10 miejsc na polu, odległych od siebie o około $10 \mathrm{~m}$. Glebę przywożono do laboratorium i przechowywano w chłodnym miejscu, bez dostępu światła, w woreczkach foliowych, przez okres nie dłuższy niż 2 tygodnie. Następnie każdą z prób mieszano $\mathrm{z}$ kwaśnym torfem o $\mathrm{pH}$ 3,5 w proporcji: 2 części badanej gleby i 1 część kwaśnego torfu. Oba komponenty bardzo dokładnie mieszano, rozbijając uprzednio wszystkie większe grudki gleby. Tak przygotowaną ziemię umieszczano w czterech doniczkach na doniczkopalecie DP7/28 znajdującej się na tacy DP2 (PPH Roko, Lenartowice, Pleszew).

Występowanie pierwotniaka badano przy pomocy biotestu na roślinach podatnego genotypu Brassica rapa ssp. pekinensis Pe-Tsai 'One Kilo SB' F1 oraz na roślinach rzepaku ozimego odmiany Monolit - podatnej na kiłę kapusty. Nasiona obu form wysiewano do mieszaniny gleby z kwaśnym torfem, po 5 nasion do 4 doniczek w doniczkopalecie. Obserwacje zdrowotności roślin wykonywano po upływie 8 tygodni od wysiewu. Oceniano zdrowotność systemu korzeniowego i ogólną kondycję roślin, według skali $0-4$, gdzie 0 - oznaczało roślinę o zdrowym systemie korzeniowym, natomiast 4 - oznaczało korzeń zdeformowany przez patogena, całkowicie przekształcony w narośl. W celu wykonania obserwacji, wszystkie rośliny wyjmowano $\mathrm{z}$ podłoża, a korzenie płukano w wodzie, dla łatwiejszego wykonania obserwacji. Wynik oznaczano jako pozytywny, jeśli na korzeniu odnotowano wyraźne guzy powodowane przez $P$. brassicae.

\section{Wyniki i dyskusja / Results and discussion}

W 23 na 35 badanych powiatów $(65,7 \%)$ w próbach gleby nie wykryto sprawcy choroby w ilości wystarczającej do wywołania objawów u podatnych roślin kapustowatych. Badanego pierwotniaka nie wykryto na terenie żadnej spośród gmin miejskich, gdzie można się spodziewać ewentualnego wniesienia patogena $\mathrm{z}$ warzywami kapustowatymi uprawianymi w ogrodach przydomowych i na działkach. Po przeniesieniu zarodników, np. z cząstkami gleby, czy wymyciu ich podczas powodzi na pola użytkowane rolniczo, sprawca choroby mógłby stanowić potencjalne, realne zagrożenie dla zdrowotności i wysokiego plonowania rzepaku. 


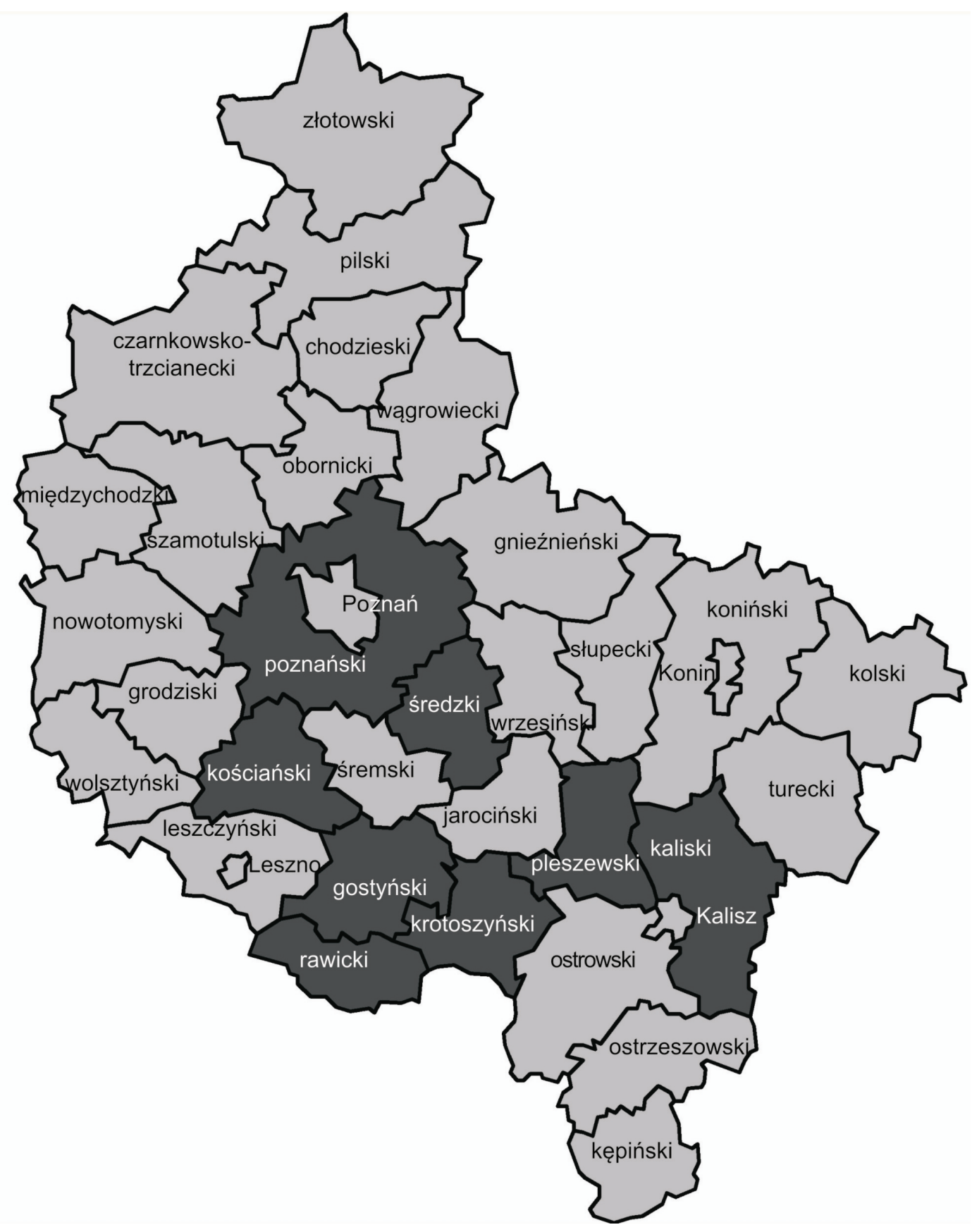

Rys. 1. Występowanie pierwotniaka $P$. brassicae w losowo pobieranych próbach gleby $\mathrm{z}$ upraw rolniczych w powiatach na terenie województwa wielkopolskiego w latach 2011-2012; jasnoszary kolor - powiaty, w których nie stwierdzono patogena, ciemnoszary - powiaty, w których stwierdzono występowanie patogena

Fig. 1. The occurrence of the protozoan pathogen P. brassicae in randomly taken samples of agricultural soils in counties on the area of Wielkopolskie voivodeship in the years of 2011-2012; light grey - counties without pathogen, dark grey - counties with pathogen

Obecność $P$. brassicae stwierdzono na pojedynczych polach położonych na terenie ośmiu powiatów wiejskich $(25,8 \%)$. Były to następujące powiaty: gostyński, kaliski, kościański, krotoszyński, średzki, poznański, pleszewski i rawicki. Autorzy wykreślili aktualną dla Wielkopolski mape z zaznaczonymi powiatami, w których stwierdzono $P$. brassicae $\mathrm{w}$ losowo pobieranych próbach gleby $\mathrm{z}$ upraw rolniczych (rys. 1).
Przeprowadzone badania wykazały, iż pierwotniak $P$. brassicae jest obecny, choć mało rozpowszechniony w glebach rolniczych w Wielkopolsce. Działania o charakterze prewencyjnym mogą w znacznym stopniu ograniczyć dalsze rozpowszechnianie się tego groźnego patogena. W Kanadzie - kraju, w którym sytuacja z kiłą kapusty jest zbliżona do obserwowanej w Polsce, podjęto szczególne środki ostrożności, których celem jest jak największe ograniczenie rozprzestrzeniania się $P$. brassicae. O ile 
jeszcze w latach 2007-2010, w kraju tym brakowało regulacji prawnych dotyczących postępowania $\mathrm{z}$ tym patogenem (Canadian Food Inspection Agency 2007; Dokken i wsp. 2010), o tyle od 2009 roku z inicjatywy Saskatchewan Clubroot Initiative rozpoczęto intensywne działania uświadamiające rolnikom zagrożenia związane z występowaniem $P$. brassicae na rzepaku. W ostatnim czasie wszczęto także liczne badania nad postępowaniem i środkami prewencyjnymi przed dalszym rozprzestrzenianiem tego patogena (Dokken-Bouchard i wsp. 2013). Podobne działania realizuje się już od dawna w Niemczech i innych krajach Europy (Rimmer i wsp. 2007; Lüders i wsp. 2011). Należy szczególnie intensywnie dążyć do wprowadzenia zbliżonych regulacji prawnych w naszym kraju, co - poza wprowadzeniem do uprawy odmian cechujących się genetyczną odpornością - może w znacznym stopniu ograniczyć zasięg i nasilenie występowania $P$. brassicae na rzepaku w Polsce.

Obecnie w naszym kraju upowszechniana jest wiedza na temat możliwości zapobiegania i ograniczania występowania kiły kapusty między innymi w ramach stosowania integrowanej ochrony rzepaku. Wydano liczne materiały informacyjne, w których podano, jak można redukować zagrożenie związane z kiłą kapusty na obszarach objętych epidemią choroby (Jajor i wsp. 2008; Korbas i Jajor 2013). Zwraca się również uwagę na duże znaczenie działań profilaktycznych w ograniczaniu porażenia roślin przez sprawcę kiły kapusty. Szczególnie zaleca się przestrzeganie właściwego płodozmianu $\mathrm{z}$ eliminowaniem uprawy roślin kapustowatych, wapnowanie, ale dopiero w roku poprzedzającym uprawę roślin podatnych, niszczenie chwastów zwłaszcza $\mathrm{z}$ tej samej rodziny, uregulowanie stosunków wodnych w glebie, staranne czyszczenie kół i maszyn po zakończeniu pracy na określonym polu, a także uprawę roślin z genami odporności (Diederichsen i wsp. 2006; Rimmer i wsp. 2007; Jajor i wsp. 2008; Kryczyński i Weber 2011; Korbas i Jajor 2013). Prowadzono także badania nad wykorzystaniem metod chemicznych w ograniczaniu kiły kapusty na rzepaku przy zastosowaniu takich substancji czynnych, jak fluazynam i tiofanat metylu (Kurowski i wsp. 2008; Jajor i wsp. 2009). Sa to środki stosowane do tej pory w uprawie warzyw kapustowatych (Robak i Gidelska 2009).

\section{Wnioski / Conclusions}

1. Objawy powodowane przez $P$. brassicae stwierdzono w próbach gleby na terenie ośmiu powiatów wiejskich województwa wielkopolskiego, co stanowi $25,8 \%$ tych powiatów. Objawów porażenia roślin przez tego patogena nie stwierdzono na polach w żadnym $\mathrm{z}$ czterech badanych powiatów miejskich.

2. Pierwotniak P. brassicae jest obecny, choć jeszcze nie jest częsty $\mathrm{w}$ glebach $\mathrm{z}$ uprawami roślin rolniczych w Wielkopolsce. Wskazane jest podjęcie działań prewencyjnych, prowadzących do ograniczenia dalszego rozprzestrzeniania się tego patogena na rzepaku, na tym terenie.

3. Biotest wykonywany na roślinach podatnych na wszystkie rasy $P$. brassicae pozwala na uzyskanie ważnych z praktycznego punktu widzenia informacji o nasileniu i zagrożeniu związanym $\mathrm{z}$ występowaniem $P$. brassicae w określonej próbie gleby.

Badania wykonano w ramach projektu Narodowego Centrum Nauki N N310 298439.

\section{Literatura / References}

Agrios G.N. 2005. Plant Pathology. 5th ed. Elsevier Academic Press, Inc. San Diego, USA, 922 pp.

Canadian Food Inspection Agency. 2007. Containment Standards for Facilities Handling Plant Pests, 1st ed. Biohazard Containment and Safety Science Branch, CFIA. http://www.inspection.gc.ca/english/sci/bio/plaveg/placone.pdf. Accessed: 31.07.2013.

Diederichsen E., Beckmann J., Schondelmeier J., Dreyer F. 2006. Genetics of clubroot resistance in Brassica napus 'Mendel'. Acta Hort. 706: $307-311$.

Dixon G. 2009. The occurrence and economic impact of Plasmodiophora brassicae and clubroot disease. J. Plant Growth Regul. 28: $194-202$

Dokken F.L., Bouchard A.J., Ippolito J., Peng G., Strelkov S.E., Kirkham L., Kutcher H.R. 2010. Detection of Plasmodiophora brassicae in Saskatchewan. Can. Plant Dis. Surv. 90, p. 126.

Dokken-Bouchard F., Vakulabharanam V., Phelps S., Northover P., Jurke C., Peng G., Gossen B. 2013. Recommendations for managing clubroot risks associated with field research. Saskatchewan Clubroot Initiative. http://canolacouncil.org/media/533217/Revised\%20Clubroot\%20Research\%20 Guidelines.pdf. Accessed: 31.07.2013.

Gossen B.D., McDonald M.R., Hwang S.F., Strelkov S.E., Peng G. 2013. A comparison of clubroot development and management on canola and Brassica vegetables. Can. J. Plant Pathol. 35 (2): 175-191.

Jajor E., Korbas M., Budka A. 2009. Ograniczanie kiły kapusty (Plasmodiophora brassicae) w rzepaku ozimym przy użyciu tiofanatu metylu. [Reduction of clubroot (Plasmodiophora brassicae) on winter oilseed rape using methyl tiophanate]. Prog. Plant Prot./Post. Ochr. Roślin 49 (3): 1268-1272.

Jajor E., Korbas M., Kozłowski J., Mrówczyński M., Pruszyński G., Wachowiak H., Walczak F., Węgorek P. 2008. Poradnik sygnalizatora ochrony rzepaku. Inst. Ochr. Roślin - PIB, Poznań, 153 ss.

Konieczny W. 2012. Kiła opanowała 250 tys. hektarów. Farmer 5: 38-42.

Korbas M., Jajor E. 2013. Kiła kapusty - narastający problem w uprawie rzepaku. Materiały informacyjne. Inst. Ochr. Roślin - PIB, Poznań, Syngenta, Warszawa, 15 ss.

Korbas M., Jajor E., Budka A. 2009. Clubroot (Plasmodiophora brassicae) - a threat for oilseed rape. J. Plant Prot. Res. 49 (4): $463-468$.

Kryczyński S., Weber Z. (red.). 2011. Fitopatologia. T. 2. Choroby roślin uprawnych. PWRiL, Poznań, 464 ss. 
Kurowski T.P., Majchrzak B., Jaźwińska E., Wysocka U. 2008. Skuteczność fungicydu zawierającego fluazynam w ochronie rzepaku przed kiłą kapusty (Plasmodiophora brassicae Woronin). [Effectiveness of a fungicide containing fluazinam for the protection of winter rape against clubroot (Plasmodiophora brassicae Woronin)]. Prog. Plant Prot./Post. Ochr. Roślin 48 (2): 893-895.

Lüders W., Abel S., Friedt W., Kopahnke D., Ordon F. 2011. Auftreten von Plasmodiophora brassicae als Erreger der Kohlhernie im Winterrapsanbau in Europa sowie Identifizierung, Charakterisierung und molekulare Kartierung neuer Kohlhernieresistenzgene aus genetischen Ressourcen Drittes Nachwuchswissenschaftlerforum, 23-25 November 2010 in Quedlinburg. Julius-Kuhn-Archiv 430: $40-43$.

Pageau D., Lajeunesse J., Lafond J. 2006. Impact of clubroot (Plasmodiophora brassicae) on the yield and quality of canola. Can. J. Plant Pathol. 28 (1): 137-143.

Rimmer S.R., Shattuck V.I., Buchwaldt I. 2007. Compendium of Brassica Diseases. The APS, St. Paul, MN, 117 pp.

Robak J. 1991. Zmienność patotypów Plasmodiophora brassicae Wor. występujących w Polsce i ich patogeniczność w stosunku do odmian i linii hodowlanych Brassica oleracea. Praca habilitacyjna. Instytut Warzywnictwa, Skierniewice 6, 59 ss.

Robak J., Gidelska A. 2009. Epidemiologia i nowe możliwości zwalczania Plasmodiophora brassicae - sprawcy kiły kapusty na roślinach kapustowatych w Polsce. [Epidemiology and new possibility of control of Plasmodiophora brassicae causal agent of clubroot of cruciferous crops in Poland]. Prog. Plant Prot./Post. Ochr. Roślin 49 (1): 268-274.

Strelkov S.E., Manolii V.P., Howard R.J., Rennie D.C., Hwang S.F., Manolii A.V., Liu J., Cao T., Xiao Q. 2009. Incidence of clubroot on canola in central Alberta in 2008. Can. Plant Dis. Surv. 89: 110-112. 